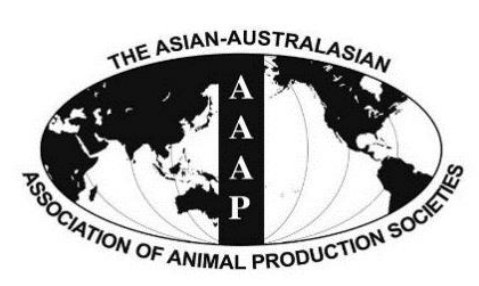

Open Access

Asian Australas. J. Anim. Sci.

Vol. 29, No. 6 : 823-829 June 2016

http://dx.doi.org/10.5713/ajas.15.0062

www.ajas.info

pISSN 1011-2367 elSSN 1976-5517

\title{
Influence of Wheat Straw Pelletizing and Inclusion Rate in Dry Rolled or Steam-flaked Corn-based Finishing Diets on Characteristics of Digestion for Feedlot Cattle
}

\author{
O. M. Manríquez, M. F. Montano*, J. F. Calderon, J. A. Valdez, J. O. Chirino, V. M. Gonzalez, \\ J. Salinas-Chavira ${ }^{1}$, G. D. Mendoza ${ }^{2}$, S. Soto ${ }^{3}$, and R. A. Zinn ${ }^{4}$ \\ Veterinary School, Autonomous University of Baja California, Mexicali 21283, México
}

\begin{abstract}
Eight Holstein steers (216 $\pm 48 \mathrm{~kg}$ body weight) fitted with ruminal and duodenal cannulas were used to evaluate effects of wheat straw processing (ground vs pelleted) at two straw inclusion rates (7\% and $14 \%$; dry matter basis) in dry rolled or steam-flaked cornbased finishing diets on characteristics of digestion. The experimental design was a split plot consisting of two simultaneous $4 \times 4$ Latin squares. Increasing straw level reduced ruminal $(\mathrm{p}<0.01)$ and total tract $(\mathrm{p}=0.03)$ organic matter $(\mathrm{OM})$ digestion. As expected, increasing wheat straw level from $7 \%$ to $14 \%$ decreased $(\mathrm{p}<0.05)$ ruminal and total tract digestion of OM. Digestion of neutral detergent fiber (NDF) and starch, per se, were not affected $(\mathrm{p}>0.10)$ by wheat straw level. Likewise, straw level did not influence ruminal acetate and propionate molar proportions or estimated methane production $(\mathrm{p}>0.10)$. Pelleting straw did not affect $(\mathrm{p} \geq 0.48)$ ruminal digestion of OM, NDF, and starch, or microbial efficiency. Ruminal feed $\mathrm{N}$ digestion was greater $(7.4 \% ; \mathrm{p}=0.02)$ for ground than for pelleted wheat straw diets. Although ruminal starch digestion was not affected by straw processing, post-ruminal $(\mathrm{p}<0.01)$, and total-tract starch $(\mathrm{p}=0.05)$ digestion were greater for ground than for pelleted wheat straw diets, resulting in a tendency for increased post-ruminal $(\mathrm{p}=0.06)$ and total tract $(\mathrm{p}=0.07)$ OM digestion. Pelleting wheat straw decreased $(\mathrm{p}<0.01)$ ruminal $\mathrm{pH}$, although ruminal volatile fatty acids (VFA) concentration and estimated methane were not affected $(\mathrm{p} \geq 0.27)$. Ruminal digestion of $\mathrm{OM}$ and starch, and post-ruminal and total tract digestion of OM, starch and $\mathrm{N}$ were greater ( $\mathrm{p}<0.01)$ for steamflaked than for dry rolled corn-based diets. Ruminal NDF digestion was greater $(p=0.02)$ for dry rolled than for steam-flaked corn, although total tract NDF digestion was unaffected $(\mathrm{p}=0.94)$. Ruminal microbial efficiency and ruminal degradation of feed $\mathrm{N}$ were not affected ( $\mathrm{p}>0.14)$ by corn processing. However, microbial $\mathrm{N}$ flow to the small intestine and ruminal $\mathrm{N}$ efficiency (non-ammonia $\mathrm{N}$ flow to the small intestine/ $\mathrm{N}$ intake) were greater $(\mathrm{p}<0.01)$ for steam-flaked than for dry rolled corn-based diets. Ruminal $\mathrm{pH}$ and total VFA concentration were not affected $(\mathrm{p} \geq 0.16)$ by corn processing method. Compared with dry rolled corn, steam-flaked corn-based diets resulted in decreased acetate:propionate molar ratio $(\mathrm{p}=0.02)$. It is concluded that at $7 \%$ or $14 \%$ straw inclusion rate, changes in physical characteristics of wheat straw brought about by pelleting negatively impact OM digestion of both steam-flaked and dry-rolled corn-based finishing diets. This effect is due to decreased postruminal starch digestion. Replacement of ground straw with pelleted straw also may decrease ruminal pH. (Key Words: Digestion, Cattle, Wheat Straw, Corn Grain, Processing)
\end{abstract}

\section{INTRODUCTION}

Wheat is the principal agronomic crop of the Mexicali

\footnotetext{
* Corresponding Author: M. F. Montano. Tel: +52-686-563-69-10, Fax: +52-686-563-69-10, E-mail: martinmg@uabc.edu.mx

${ }^{1}$ Veterinary School, Autonomous University of Tamaulipas, Cd. Victoria, 87078, México.

${ }^{2}$ Department of Agricultural and Animal Production, Autonomous Metropolitan University, Xochimilco 04960, México.

3 Department of Animal and Range Sciences, New Mexico State University, Las Cruces NM 88007, USA.

${ }^{4}$ Department of Animal Science, University of California, Davis CA 95616, USA.

Submitted Jan. 24, 2015; Revised Mar. 30, 2015; Accepted Jul. 10, 2015
}

Valley. After the grain is harvested, much of the straw is left in the field. The relatively low available energy value of wheat straw limits its nutritive value for feedlot cattle (Lesoing et al., 1980). However, its functional value as a roughage source is well documented (Ware and Zinn, 2005; Salinas-Chavira et al., 2013). Hence, the level of inclusion of wheat straw in high-concentrate finishing diets is largely a functional constraint, i.e. stimulate chewing and saliva output that buffer the acids produced during ruminal fermentation (Balch, 1958). Feedlot receiving diets typically include approximately $35 \%$ roughage to allow adaptation of ruminal bacteria to the more readily 
fermentable carbohydrates (Berry et al., 2004). Whereas, finishing diets contain $4.5 \%$ to $13.5 \%$ (dry matter [DM] basis) roughage (Vasconcelos and Galyean, 2007). Both roughage concentration and physical form contribute to normal rumen function (Woodford et al., 1986). Pelletizing forages affects its functionality as roughage. It increases particle density and ruminal passage rate, reducing total chewing activity and rumination (Mertens, 1997; Mertens and Ely, 1979). However, the increased density brought about by pelletizing wheat straw would reduce transportation cost over long distances from areas of wheat production to feedlot centers, and enhance conveyance, mixing, and feed delivery of otherwise bulkier finishing diets. The comparative effects of level of inclusion conventional ground vs pelleting wheat straw on characteristics of digestion of finishing diets for feedlot cattle has not been previously evaluated. Steam-flaking improves starch digestibility over that of dry-rolled corn (Zinn et al., 2002). However, in the absence of adequate roughage the enhanced starch digestibility may reduce ruminal $\mathrm{pH}$ (Zinn et al., 1995) to the extent that it depresses organic matter (OM) digestion and associated digestive processes, leading to suboptimal average daily gain and gain efficiency (Owens et al., 1986). The objectives of this experiment were to evaluate the influence of wheat straw level and processing method on characteristics of digestion of dry rolled or steam-flaked corn (SFC)-based finishing diets.

\section{MATERIALS AND METHODS}

All procedures involving animal care and management were in accordance with and approved by the University of California, Davis, Animal Use and Care Committee.

Eight Holstein steers $(216 \pm 48 \mathrm{~kg})$ fitted with ruminal and duodenal cannulas were used in a split plot design consisting of two simultaneous $4 \times 4$ Latin squares to evaluate the influence of wheat straw level ( $7 \%$ vs $14 \%$, DM basis) and processing method (ground vs pelleting) on characteristics of digestion of dry rolled and SFC-based finishing diets for feedlot cattle. Wheat straw level and processing method were evaluated in a $2 \times 2$ factorial arrangement within each $4 \times 4$ Latin square design in which diets contained either dry rolled or SFC (whole plots). Composition of experimental diets is shown in Table 1. Diets included $0.35 \%$ chromic oxide as an indigestible marker to estimate nutrient flows and digestibility. Chromic oxide was premixed with minor ingredients (urea, limestone and trace mineral salt) before incorporation into complete mixed diets. The eight treatments were: $7 \%$ ground wheat straw (GRWS) with dry rolled corn (DRC); 7\% pelleted wheat straw (PEWS) with DRC; 14\% GRWS with DRC; 14\% PEWS with DRC; 7\% GRWS with SFC; 7\% PEWS with SFC; $14 \%$ GRWS with SFC; $14 \%$ PEWS with SFC. GRWS was processed in a hammer mill (Bear Cat \#1A-S, Westerns Land and Roller Co., Hastings, NE, USA), equipped with a $3.81 \mathrm{~cm}$ screen. Pelleting wheat straw (PEWS, $2 \times 0.5 \mathrm{~cm}$ pellets) was produced using a California Pellet Mill. SFC was prepared as follows. A chest situated directly above the rollers $(46 \times 61 \mathrm{~cm}$, corrugated) was filled with $441 \mathrm{~kg}$ of yellow corn and then brought to a constant temperature of $102^{\circ} \mathrm{C}$ at atmospheric pressure using steam. Grain was steamed for 20 min before starting the rollers. Approximately $454 \mathrm{~kg}$ of the initial steam-processed grain that exited the rollers during the warm-up of the rollers was set aside and not fed to the cattle in this study. The roller tension was adjusted to provide a flake density of $0.31 \mathrm{~kg} / \mathrm{L}$. Average retention time in the steam chamber was approximately $30 \mathrm{~min}$. The SFC was allowed to air-dry before use in diet preparation. Dry rolled corn was prepared by rolling corn in the absence of steam with roller tension set to provide a density of $0.58 \mathrm{~kg} / \mathrm{L}$.

Steers were housed in individual pens $\left(3.9 \mathrm{~m}^{2}\right)$ with concrete floor covered by neoprene carpet, automatic waterers and individual feed bunks. Diets were fed at 0800 and $2000 \mathrm{~h}$ daily. Dry matter intake was restricted to 3.94 $\mathrm{kg} / \mathrm{d}$. The experiment consisted of four 14-d periods, consisting of $10 \mathrm{~d}$ for diet adjustment plus $4 \mathrm{~d}$ for sample collection. During collection, duodenal and fecal samples were taken from each steer twice daily over a period of 4 successive days as follows: d 1, 0750 and $1350 \mathrm{~h}$; d 2, 0900 and $1500 \mathrm{~h} ; \mathrm{d} \mathrm{3,} 1050$ and $1650 \mathrm{~h}$; and d, 1200 and $1800 \mathrm{~h}$. Individual samples consisted of approximately $700 \mathrm{~mL}$ of duodenal chyme and $200 \mathrm{~g}$ (wet basis) of fecal material. Samples for each steer within each collection period were composited for analysis. During the final day of each collection period, ruminal samples were obtained from each steer via the ruminal cannula at $4 \mathrm{~h}$ after feeding. Ruminal fluid $\mathrm{pH}$ was determined on freshly collected samples. Samples were then strained through four layers of cheesecloth. Two milliliters of freshly prepared $25 \%$ (wt/vol) meta-phosphoric acid was added to $8 \mathrm{~mL}$ of strained ruminal fluid. Samples were then centrifuged $(17,000 \times \mathrm{g}$ for $10 \mathrm{~min})$, and supernatant fluid was stored at $-20^{\circ} \mathrm{C}$ for volatile fatty acids (VFA) analysis. Upon completion of the experiment, ruminal fluid was obtained via the ruminal cannula from all steers and composited for isolation of ruminal bacteria via differential centrifugation (Bergen et al., 1968).

Feed and fecal samples were subjected to the following analysis: DM (oven drying at $105^{\circ} \mathrm{C}$ until no further weight loss); ash (method 942.05, AOAC, 1986), Kjeldahl N (method 984.13, AOAC, 2000); aNDFom (Van Soest et al., 1991, corrected for neutral detergent fiber (NDF)-ash, incorporating heat stable $\alpha$-amylase [Ankom FAA, Ankom Technology, Macedon, NY, USA] at $1 \mathrm{~mL}$ per $100 \mathrm{~mL}$ of 
Table 1. Composition of the experimental diets fed to the steers

\begin{tabular}{|c|c|c|c|c|c|c|c|c|}
\hline \multirow{3}{*}{ Items } & \multicolumn{4}{|c|}{ Steam flaked corn } & \multicolumn{4}{|c|}{ Dry rolled corn } \\
\hline & \multicolumn{2}{|c|}{$14 \%$ wheat straw } & \multicolumn{2}{|c|}{$7 \%$ wheat straw } & \multicolumn{2}{|c|}{$14 \%$ wheat straw } & \multicolumn{2}{|c|}{$7 \%$ wheat straw } \\
\hline & Gro & Pell & Gro & Pell & Gro & Pell & Gro & Pell \\
\hline \multicolumn{9}{|l|}{ Ingredients (\%, DM basis) } \\
\hline Steam-flaked corn & 70.00 & 70.00 & 77.00 & 77.00 & 0.0 & 0.0 & 0.0 & 0.0 \\
\hline Dry Rolled corn & 0.0 & 0.0 & 0.0 & 0.0 & 70.00 & 70.00 & 77.00 & 77.00 \\
\hline Wheat straw, ground & 14.00 & 0.0 & 7.00 & 0.0 & 14.00 & 0.0 & 7.00 & 0.0 \\
\hline Wheat straw, pelleted & 0.0 & 14.00 & 0.0 & 7.00 & 0.0 & 14.00 & 0.0 & 7.00 \\
\hline Cane molasses & 6.00 & 6.00 & 6.00 & 6.00 & 6.00 & 6.00 & 6.00 & 6.00 \\
\hline Pelleted canola & 3.70 & 3.70 & 3.70 & 3.70 & 3.70 & 3.70 & 3.70 & 3.70 \\
\hline Yellow grease & 2.80 & 2.80 & 2.80 & 2.80 & 2.80 & 2.80 & 2.80 & 2.80 \\
\hline Limestone & 1.40 & 1.40 & 1.40 & 1.40 & 1.40 & 1.40 & 1.40 & 1.40 \\
\hline Urea & 1.30 & 1.30 & 1.30 & 1.30 & 1.30 & 1.30 & 1.30 & 1.30 \\
\hline TM salt ${ }^{1}$ & 0.35 & 0.35 & 0.35 & 0.35 & 0.35 & 0.35 & 0.35 & 0.35 \\
\hline Chromic oxide & 0.35 & 0.35 & 0.35 & 0.35 & 0.35 & 0.35 & 0.35 & 0.35 \\
\hline Magnesium oxide & 0.10 & 0.10 & 0.10 & 0.10 & 0.10 & 0.10 & 0.10 & 0.10 \\
\hline \multicolumn{9}{|c|}{ Nutrient composition, DM basis (based on NRC, 2000) } \\
\hline \multicolumn{9}{|c|}{$\mathrm{NE}(\mathrm{Mcal} / \mathrm{kg})$} \\
\hline Maintenance & 2.08 & 2.08 & 2.20 & 2.20 & 1.94 & 1.94 & 2.05 & 2.05 \\
\hline Gain & 1.43 & 1.43 & 1.54 & 1.54 & 1.30 & 1.30 & 1.40 & 1.40 \\
\hline $\mathrm{CP}(\%)$ & 13.26 & 13.26 & 13.68 & 13.68 & 13.47 & 13.47 & 13.91 & 13.91 \\
\hline Ether extract $(\%)$ & 6.40 & 6.40 & 6.56 & 6.56 & 6.40 & 6.40 & 6.56 & 6.56 \\
\hline Nonstructural $\mathrm{CHO}(\%)$ & 58.05 & 58.05 & 63.38 & 63.38 & 58.15 & 58.15 & 63.49 & 63.49 \\
\hline $\operatorname{NDF}(\%)$ & 18.41 & 18.41 & 13.51 & 13.51 & 18.40 & 18.40 & 13.51 & 13.51 \\
\hline $\mathrm{Ca}(\%)$ & 0.70 & 0.70 & 0.69 & 0.69 & 0.70 & 0.70 & 0.70 & 0.70 \\
\hline $\mathrm{P}(\%)$ & 0.28 & 0.28 & 0.30 & 0.30 & 0.28 & 0.28 & 0.30 & 0.30 \\
\hline $\mathrm{K}(\%)$ & 0.69 & 0.69 & 0.62 & 0.62 & 0.69 & 0.69 & 0.62 & 0.62 \\
\hline $\operatorname{Mg}(\%)$ & 0.26 & 0.26 & 0.26 & 0.26 & 0.26 & 0.26 & 0.26 & 0.26 \\
\hline $\mathrm{S}(\%)$ & 0.19 & 0.19 & 0.19 & 0.19 & 0.19 & 0.19 & 0.19 & 0.19 \\
\hline
\end{tabular}

Gro, ground; Pell, pelleted; DM, dry matter; TM, trace mineral; NE, net energy; CP, crude protein; NDF, neutral detergent fiber.

${ }^{1} \mathrm{TM}$ salt contained (g/kg): $\mathrm{CoSO} 4,6.8 ; \mathrm{CuSO} 4,10.4 ; \mathrm{FeSO} 4,35.7 ; \mathrm{ZnO}, 12.4 ; \mathrm{MnSO} 4,10.7 ; \mathrm{KI}, 0.52 ; \mathrm{NaCl}$, 929.6.

NDF solution); chromic oxide (Hill and Anderson, 1958); and starch (Zinn, 1990). Duodenal samples were subjected the following analysis: DM (oven drying at $105^{\circ} \mathrm{C}$ until no further weight loss); ash (method 942.05, AOAC, 1986), Kjeldahl N (method 984.13, AOAC, 2000), ammonia N (method 941.04, AOAC, 2000); aNDFom [Van Soest et al., 1991 , corrected for NDF-ash, incorporating heat stable $\alpha$ amylase [Ankom FAA, Ankom Technology, USA] at $1 \mathrm{~mL}$ per $100 \mathrm{~mL}$ of NDF solution); purines (Zinn and Owens, 1986); chromic oxide (Hill and Anderson, 1958); and starch (Zinn, 1990). Duodenal flow and fecal excretion of DM were calculated based on marker ratio, using chromic oxide. Microbial organic matter (MOM) and N (MN) leaving the abomasum was calculated using purines as a microbial marker (Zinn and Owens, 1986).

Organic matter fermented in the rumen was considered equal to $\mathrm{OM}$ intake minus the difference between the amount of total OM reaching the duodenum and MOM reaching the duodenum. Feed $\mathrm{N}$ escape to the small intestine was considered equal to total $\mathrm{N}$ leaving the abomasum minus ammonia-N, $\mathrm{MN}$ and endogenous $\mathrm{N}$ $\left(0.195 \times \mathrm{BW}^{0.75}\right.$; Ørskov et al., 1986). Methane production (mol/mol glucose equivalent fermented) was estimated based on the theoretical fermentation balance for observed molar distribution of VFA (Wolin, 1960).

The trial was evaluated as a split plot design consisting of two simultaneous $4 \times 4$ Latin squares according to the model: $\mathrm{Y}_{\mathrm{ijkl}}=\mathrm{m}+\mathrm{B}_{\mathrm{i}}+\mathrm{A}_{\mathrm{j}(\mathrm{i})}+\mathrm{P}_{\mathrm{k}}+\mathrm{T}_{\mathrm{l}}+\mathrm{BT}_{\mathrm{ij}}+\mathrm{e}_{\mathrm{ijkl}}, \mathrm{B}_{\mathrm{i}}$ is whole plot (corn processing), $\mathrm{A}_{\mathrm{j}(\mathrm{i})}$ is steer with whole plot, $\mathrm{P}_{\mathrm{k}}$ is period, $\mathrm{T}_{1}$ is wheat straw level x processing subplot treatments, $\mathrm{BT}_{\mathrm{ij}}$ is whole plot $\times$ subplot treatment interaction and $\mathrm{e}_{\mathrm{ijkl}}$ is residual error. Wheat straw level and processing method were evaluated in a $2 \times 2$ factorial arrangement within each $4 \times 4$ Latin square design (general linear model procedure; SAS 2007).

\section{RESULTS AND DISCUSSION}

Treatment effects on characteristics of digestion and ruminal $\mathrm{pH}$ and VFA molar proportions are shown in Table 
2 and 3. There were no treatment interactions ( $\mathrm{p}=0.10$ to 0.99 ) on characteristics of ruminal and total tract digestion.

\section{Wheat straw level $(7 \%$ vs $14 \%)$}

As expected, increasing wheat straw level from $7 \%$ to $14 \%$ decreased $(\mathrm{p}<0.05)$ ruminal and total tract digestion of OM. Wheat straw partially replaced corn grain in the diet. The decrease in $\mathrm{OM}$ digestion is expected due to the substitution of corn grain with less digestible wheat straw. This decrease of OM digestion with increased wheat straw inclusion rate is consistent with previous studies (CalderonCortes and Zinn, 1996; Salinas-Chavira et al., 2013).
Consistent with previous studies (Zinn, 1986; Zinn et al., 1994; Calderon-Cortes and Zinn, 1996; Salinas-Chavira et al., 2013), digestion of NDF and starch, per se, were not affected $(\mathrm{p}>0.10)$ by wheat straw level. Microbial $\mathrm{N}$ efficiency ( $\mathrm{g} \mathrm{MN} / \mathrm{kg} \mathrm{OM}$ fermented) and microbial $\mathrm{N}$ flow to duodenum were likewise unaffected $(p>0.10)$ by roughage level. Microbial $\mathrm{N}$ efficiency is expected to increase with increased forage level, associated with increased ruminal $\mathrm{pH}$ and dilution rate (NRC, 2000). However, this effect has not been consistent. Zinn et al. (1994) likewise did not observe an effect of increasing forage level from $10 \%$ to $20 \%$ in a SFC-based finishing on

Table 2. Influence of wheat straw level and processing, and corn grain processing on characteristics of ruminal and total digestion of steers fed finishing diets (main effects)

\begin{tabular}{|c|c|c|c|c|c|c|c|c|c|c|c|c|}
\hline \multirow{3}{*}{ Items } & \multicolumn{6}{|c|}{ Main effects } & \multirow[b]{3}{*}{ SEM } & \multicolumn{5}{|c|}{ p-value } \\
\hline & \multicolumn{2}{|c|}{ Straw level ${ }^{1}$} & \multicolumn{2}{|c|}{ Straw process } & \multicolumn{2}{|c|}{ Grain process } & & \multicolumn{3}{|c|}{ Straw } & \multicolumn{2}{|c|}{ Grain } \\
\hline & $7 \%$ & $14 \%$ & Gro & Pell & DRC & SFC & & $\begin{array}{c}7 \% \text { vs } \\
14 \%\end{array}$ & $\begin{array}{c}\text { Gro vs } \\
\text { Pell }\end{array}$ & $\begin{array}{l}\text { Level× } \\
\text { process }\end{array}$ & $\begin{array}{c}\text { DRC vs } \\
\text { SFC }\end{array}$ & $\begin{array}{c}\text { Straw } \times \\
\text { grain }\end{array}$ \\
\hline Steer replication & 8 & 8 & 8 & 8 & 16 & 16 & - & - & - & - & - & - \\
\hline \multicolumn{13}{|l|}{ Intake $(\mathrm{g} / \mathrm{d})$} \\
\hline $\mathrm{DM}$ & 4,700 & 4,700 & 4,700 & 4,700 & 4,700 & 4,700 & - & - & - & - & - & - \\
\hline $\mathrm{OM}$ & 4,466 & 4,421 & 4,455 & 4,433 & 4,431 & 4,456 & - & - & - & - & - & - \\
\hline NDF & 545 & 726 & 643 & 627 & 634 & 637 & - & - & - & - & - & - \\
\hline $\mathrm{N}$ & 94 & 92 & 93 & 93 & 93 & 94 & - & - & - & - & - & - \\
\hline Starch & 2,590 & 2,411 & 2,509 & 2,492 & 2,345 & 2,656 & - & - & - & - & - & - \\
\hline \multicolumn{13}{|l|}{ Duodenal flow (g/d) } \\
\hline $\mathrm{OM}$ & 2,244 & 2,387 & 2,324 & 2,307 & 2,888 & 2,142 & 51.24 & 0.02 & 0.74 & 0.40 & $<0.01$ & 0.99 \\
\hline $\mathrm{NDF}$ & 324 & 457 & 390 & 391 & 357 & 424 & 27.33 & $<0.01$ & 0.97 & 0.75 & 0.05 & 0.99 \\
\hline Starch & 551 & 514 & 546 & 519 & 731 & 334 & 33.85 & 0.29 & 0.45 & 0.29 & $<0.01$ & 0.90 \\
\hline $\mathrm{N}$ & 99 & 101 & 99 & 100 & 90 & 109 & 3.38 & 0.49 & 0.71 & 0.52 & $<0.01$ & 0.98 \\
\hline NH-N & 5.70 & 6.37 & 6.27 & 5.81 & 6.39 & 5.68 & 0.49 & 0.19 & 0.37 & 0.63 & 0.19 & 0.71 \\
\hline NAN & 93 & 95 & 93 & 95 & 84 & 103 & 3.14 & 0.60 & 0.59 & 0.44 & $<0.01$ & 0.99 \\
\hline MN & 66 & 64 & 67 & 64 & 57 & 74 & 2.48 & 0.49 & 0.21 & 0.58 & $<0.01$ & 0.96 \\
\hline \multicolumn{13}{|l|}{ Ruminal digestion (\%) } \\
\hline $\mathrm{OM}$ & 0.648 & 0.612 & 0.634 & 0.626 & 0.574 & 0.686 & 0.012 & $<0.01$ & 0.49 & 0.50 & $<0.01$ & 0.81 \\
\hline NDF & 0.409 & 0.392 & 0.411 & 0.390 & 0.458 & 0.343 & 0.038 & 0.66 & 0.59 & 0.61 & 0.02 & 0.91 \\
\hline Starch & 0.783 & 0.785 & 0.781 & 0.787 & 0.693 & 0.875 & 0.014 & 0.89 & 0.66 & 0.27 & $<0.01$ & 0.54 \\
\hline Feed N & 0.830 & 0.793 & 0.840 & 0.782 & 0.823 & 0.799 & 0.021 & 0.10 & 0.02 & 0.75 & 0.30 & 0.30 \\
\hline Microbial efficiency $^{2}$ & 22.82 & 23.90 & 23.70 & 23.02 & 22.56 & 24.15 & 0.930 & 0.26 & 0.48 & 0.37 & 0.14 & 0.67 \\
\hline $\mathrm{N}$ efficiency & 0.99 & 1.02 & 1.00 & 1.02 & 0.91 & 1.11 & 0.036 & 0.35 & 0.52 & 0.31 & $<0.01$ & 0.23 \\
\hline \multicolumn{13}{|c|}{ Postruminal digestion ( $\%$ flow to duodenum) } \\
\hline $\mathrm{OM}$ & 0.586 & 0.552 & 0.590 & 0.548 & 0.529 & 0.609 & 0.021 & 0.12 & 0.06 & 0.97 & $<0.01$ & 0.79 \\
\hline $\mathrm{N}$ & 0.718 & 0.709 & 0.722 & 0.704 & 0.646 & 0.780 & 0.016 & 0.57 & 0.27 & 0.59 & $<0.01$ & 0.13 \\
\hline Starch & 0.838 & 0.823 & 0.872 & 0.789 & 0.782 & 0.880 & 0.022 & 0.51 & $<0.01$ & 0.79 & $<0.01$ & 0.39 \\
\hline \multicolumn{13}{|c|}{ Total tract digestion $(\%)$} \\
\hline $\mathrm{DM}$ & 0.764 & 0.733 & 0.762 & 0.735 & 0.716 & 0.780 & 0.001 & 0.05 & 0.09 & 0.45 & $<0.01$ & 0.37 \\
\hline $\mathrm{OM}$ & 0.791 & 0.762 & 0.789 & 0.764 & 0.741 & 0.812 & 0.013 & 0.03 & 0.07 & 0.63 & $<0.01$ & 0.33 \\
\hline NDF & 0.419 & 0.406 & 0.437 & 0.387 & 0.414 & 0.411 & 0.039 & 0.74 & 0.22 & 0.29 & 0.94 & 0.62 \\
\hline $\mathrm{N}$ & 0.714 & 0.687 & 0.711 & 0.690 & 0.657 & 0.744 & 0.015 & 0.08 & 0.18 & 0.21 & $<0.01$ & 0.33 \\
\hline Starch & 0.958 & 0.960 & 0.969 & 0.949 & 0.933 & 0.986 & 0.009 & 0.85 & 0.05 & 0.72 & $<0.01$ & 0.10 \\
\hline
\end{tabular}

Gro, ground; Pell, pelleted; DRC, dry rolled corn; SFC, steam flaked corn; SEM, standard error of the mean; DM, dry metter; OM, organic matter; $\mathrm{NDF}$, neutral detergent fiber.

${ }^{1}$ Level, $7 \%$ or $14 \%$ of diet. ${ }^{2}$ Microbial N, g/kg of OM fermented. 
Table 3. Influence of wheat straw level and processing, and corn grain processing on ruminal $\mathrm{pH}$ and VFA molar proportions of steers fed finishing diets (main effects)

\begin{tabular}{|c|c|c|c|c|c|c|c|c|c|c|c|c|}
\hline \multirow{3}{*}{ Items } & \multicolumn{6}{|c|}{ Main effects } & \multirow[b]{3}{*}{ SEM } & \multicolumn{5}{|c|}{ p-value } \\
\hline & \multicolumn{2}{|c|}{ Straw level ${ }^{1}$} & \multicolumn{2}{|c|}{ Straw process } & \multicolumn{2}{|c|}{ Grain process } & & \multicolumn{3}{|c|}{ Straw } & \multicolumn{2}{|c|}{ Grain } \\
\hline & $7 \%$ & $14 \%$ & Gro & Pell & $\mathrm{DRC}$ & SFC & & $\begin{array}{c}7 \% \text { vs } \\
14 \%\end{array}$ & $\begin{array}{c}\text { Gro vs } \\
\text { Pell }\end{array}$ & $\begin{array}{l}\text { Level× } \\
\text { process }\end{array}$ & $\begin{array}{c}\text { DRC vs } \\
\text { SFC }\end{array}$ & $\begin{array}{c}\text { Straw } \times \\
\text { grain }\end{array}$ \\
\hline Steer replication & 8 & 8 & 8 & 8 & 16 & 16 & - & - & - & - & - & - \\
\hline $\mathrm{pH}$ & 5.58 & 5.71 & 5.78 & 5.50 & 5.68 & 5.60 & 0.08 & 0.14 & $<0.01$ & 0.07 & 0.36 & 0.95 \\
\hline Total VFA & 71.07 & 70.21 & 69.52 & 71.77 & 72.95 & 68.33 & 2.87 & 0.77 & 0.44 & 0.75 & 0.16 & 0.65 \\
\hline \multicolumn{13}{|c|}{ Molar proportion VFA } \\
\hline Acetate & 67.98 & 68.49 & 68.05 & 67.98 & 70.57 & 65.90 & 1.45 & 0.73 & 0.80 & 0.38 & 0.02 & 0.85 \\
\hline Propionate & 26.28 & 25.77 & 25.91 & 26.14 & 23.55 & 28.50 & 1.44 & 0.73 & 0.87 & 0.27 & 0.01 & 0.85 \\
\hline Butyrate & 5.74 & 5.74 & 5.67 & 5.81 & 5.88 & 5.61 & 0.12 & 0.98 & 0.27 & 0.01 & 0.07 & 0.81 \\
\hline Acetate/propionate & 2.66 & 2.83 & 2.74 & 2.75 & 3.08 & 2.41 & 0.20 & 0.41 & 0.97 & 0.40 & 0.02 & 0.91 \\
\hline Methane $^{2}$ & 0.57 & 0.58 & 0.58 & 0.57 & 0.61 & 0.54 & 0.02 & 0.73 & 0.85 & 0.31 & 0.02 & 0.86 \\
\hline
\end{tabular}

VFA, volatile fatty acids; Gro, ground; Pell, pelleted; DRC, dry rolled corn; SFC, steam flaked corn; SEM, standard error of the mean.

${ }^{1}$ Level, $7 \%$ or $14 \%$ of diet.

${ }^{2}$ Methane production ( $\mathrm{mol} / \mathrm{mol}$ of glucose equivalent fermented) was estimated based on the theoretical fermentation balance for observed molar distribution of VFA (Wolin, 1960).

microbial $\mathrm{N}$ efficiency.

Wheat straw level did not influence ruminal VFA molar proportions of acetate and propionate, or estimated methane production $(p>0.10)$. However, there was an interaction between wheat straw level and processing $(p=0.01)$ on molar proportions of butyrate. Diets with $14 \%$ ground, $14 \%$ pelleted, 7\% ground, and 7\% PEWS had butyrate molar proportions of $6.21 \%, 5.74 \%, 5.59 \%$, and $5.96 \%$, respectively. There was a tendency $(\mathrm{p}=0.07)$ for an interaction between wheat straw level and processing on ruminal $\mathrm{pH}$, which decreased from 5.93 to 5.49, respectively, for diets with $14 \%$ ground vs PEWS. Whereas, ruminal $\mathrm{pH}$ decreased from 5.63 to 5.52 , respectively for diets containing 7\% ground vs PEWS. Thus, with GRWS, increasing the inclusion rate resulted in an anticipated increase in ruminal pH (Zinn et al., 1994; Calderon-Cortes and Zinn, 1996; Salinas-Chavira et al., 2013). However, with PEWS increasing inclusion rate may not result in increased ruminal $\mathrm{pH}$.

\section{Wheat straw processing (ground vs pelleted)}

Wheat straw processing did not affect $(\mathrm{p} \geq 0.48)$ ruminal digestion of OM, NDF and starch, or microbial efficiency. Ruminal feed N digestion was greater $(7.4 \% ; \mathrm{p}=0.02)$ for ground than for PEWS diets, possibly reflecting a tendency for greater ruminal retention time for diets containing GRWS (Mertens and Ely, 1979). Although ruminal starch digestion was not affected by wheat straw processing, postruminal $(\mathrm{p}<0.01)$, and total-tract starch $(\mathrm{p}=0.05)$ digestion were greater for ground than for PEWS straw diets. The increased starch digestion associated with ground vs PEWS resulted in a tendency for increased post-ruminal $(p=0.06)$ and total tract $(\mathrm{p}=0.07) \mathrm{OM}$ digestion. The basis for this effect is not certain. In other studies comparing ground vs pelleted rice straw (Ware and Zinn, 2005; Salinas Chavira et al., 2013), pelleting did not affect total tract OM digestion. Consistent with Ware and Zinn (2005), pelleting wheat straw did not affect $(p>0.22)$ site and extent of NDF digestion.

Pelleting wheat straw decreased $(\mathrm{p}<0.01)$ ruminal $\mathrm{pH}$, although ruminal VFA concentration and estimated methane were not affected $(\mathrm{p} \geq 0.27)$. The decreased ruminal $\mathrm{pH}$ associated with PEWS is consistent with previous studies comparing ground vs pelleted rice straw (Ware and Zinn, 2005; Salinas Chavira et al., 2013), and may be attributable to decreased rumination (Mertens, 1997).

\section{Grain processing (dry rolled vs steam-flaked)}

Consistent with previous studies (Zinn et al., 1998), ruminal digestion of OM and starch, and post-ruminal and total tract digestion of $\mathrm{OM}$, starch and $\mathrm{N}$ were greater $(\mathrm{p}<0.01)$ for steam-flaked than for DRC-based diets. As an aside, observed total tract starch digestion for dry rolled and SFC are also in close agreement $(99.5 \%)$ with estimated starch digestion ( $92.9 \%$ and $98.1 \%$, respectively) based on fecal starch (starch digestion, \% $=100.5-0.649$ fecal starch; Zinn et al., 2002), where fecal starch for dry rolled and SFC-diets averaged $3.6 \%$ and $11.7 \%$, respectively.

Ruminal NDF digestion was greater $(p=0.02)$ for dry rolled than for SFC. Decreased ruminal NDF digestion is also a consistent effect of steam-flake vs DRC-based diets (Corona et al., 2006). However, in the present study compensatory post-ruminal digestion sufficed to the extent that total tract digestion of NDF was unaffected $(p=0.94)$ by corn processing.

Ruminal microbial efficiency (g microbial N/kg of OM fermented) and ruminal degradation of feed $\mathrm{N}$ were not affected $(p>0.14)$ by corn processing. However, microbial 
$\mathrm{N}$ flow to the small intestine and ruminal $\mathrm{N}$ efficiency (nonammonia $\mathrm{N}$ flow to the small intestine/ $\mathrm{N}$ intake) were greater $(\mathrm{p}<0.01)$ for steam-flaked than for DRC-based diets. Increased ruminal $\mathrm{N}$ efficiency is a characteristic response to steam flaking corn (Prigge et al., 1978; Zinn, 1990; Zinn et al., 1995; Zinn et al., 1998), due to enhanced ruminal OM digestion and associated increases in net microbial protein synthesis.

There were no interactions $(p>0.10)$ between grain processing and wheat straw treatments on ruminal $\mathrm{pH}$, VFA molar proportions, and estimated methane production. Ruminal $\mathrm{pH}$ and total VFA concentration were not affected $(\mathrm{p} \geq 0.16)$ by corn processing method. The lack reduction in ruminal $\mathrm{pH}$ with steam-flaked vs DRC-based diets is not generally expected (Zinn et al., 1995; Corona et al., 2006). Although in some instances, the effects of steam-flaking corn on ruminal $\mathrm{pH}$ were not appreciable (Zinn et al., 1998). The magnitude of differences may be associated with flake density and/or fineness of grind of dry-process corn.

Compared with DRC, SFC-based diets resulted in decreased ruminal molar proportions of acetate and the acetate:propionate molar ratio $(\mathrm{p}=0.02)$, increased molar proportion of propionate $(\mathrm{p}=0.01)$, and tended to reduce the molar proportion of butyrate $(\mathrm{p}=0.07)$. These observations are characteristic response to steam-flaked vs dry processed corn (Zinn et al., 1995; Corona et al., 2006).

\section{CONCLUSIONS}

Results of this study indicate that at $7 \%$ or $14 \%$ straw inclusion rate, changes in physical characteristics of wheat straw brought about by pelleting may have a small negative impact on OM digestion of both steam-flaked and dryrolled corn-based finishing diets. This effect is due to decreased post-ruminal starch digestion. Replacement of ground straw with pelleted straw also may result in decreased ruminal $\mathrm{pH}$, although the effect was more pronounced a $14 \%$ than at $7 \%$ straw inclusion rate.

\section{CONFLICT OF INTEREST}

We certify that there is no conflict of interest with any financial organization regarding the material discussed in the manuscript.

\section{REFERENCES}

AOAC. 1986. Official Methods of Analysis, 13th ed. Association of Official Analytical Chemists, Washington, DC, USA.

AOAC. 2000. Official Methods of Analysis, 17th ed. Association of Official Analytical Chemists, Washington, DC, USA.

Balch, C. C. 1958. Observations on the act of eating in cattle. Br. J. Nutr. 12:330-3345.

Bergen, W. G., D. B. Purser, and J. H. Cline. 1968. Effect of ration on the nutritive quality of rumen microbial protein. J. Anim. Sci. 27:1497-1501.

Berry, B. A., C. R. Krehbiel, A. W. Confer, D. R. Gill, R. A. Smith, and M. Montelongo. 2004. Effects of dietary energy and starch concentrations for newly received feedlot calves: I. Growth performance and health. J. Anim. Sci. 82:837-844.

Calderon-Cortes, J. F. and R. A. Zinn. 1996. Influence of dietary forage level and forage coarseness of grind on growth performance and digestive function in feedlot steers. J. Anim. Sci. 74:2310-2316.

Corona, L., F. N. Owens, and R. A. Zinn. 2006. Impact of corn vitreousness and processing on site and extent of digestion by feedlot cattle. J. Anim. Sci. 84:3020-3031.

Hill, F. N. and D. L. Anderson. 1958. Comparison of metabolizable energy and productive energy determinations with growing chicks. J. Nutr. 64:587-603.

Lesoing, G., I. Rush, T. Klopfenstein, and J. Ward. 1980. Wheat straw in growing cattle diets. J. Anim. Sci. 51:257-262.

Mertens, D. R. and L. O. Ely. 1979. A dynamic model of fiber digestion and passage in the ruminant for evaluating forage quality. J. Anim. Sci. 49:1085-1095.

Mertens, D. R. 1997. Creating a system for meeting the fiber requirements of dairy cows. J. Dairy Sci. 80:1463-1481.

NRC. 2000. Nutrient Requirements of Beef Cattle, 7th Rev. Ed. National Academy Press, Washington, DC, USA.

Ørskov, E. R., N. A. MacLeod, and D. J. Kyle. 1986. Flow of nitrogen from the rumen and abomasum in cattle and sheep given protein free nutrients by intragastric infusion. Br. J. Nutr. 56:241-248.

Owens, F. N., R. A. Zinn, and Y. K. Kim. 1986. Limits to starch digestion in the ruminant small intestine. J. Anim. Sci. 63:1634-1648.

Prigge, E. C., M. L. Galyean, F. N. Owens, D. G. Wagner, and R. R. Johnson. 1978. Microbial protein synthesis in steers fed processed corn rations. J. Anim. Sci. 46:249-254.

Salinas-Chavira, J., E. Alvarez, M. F. Montaño, and R. A. Zinn. 2013. Influence of forage NDF level, source and pelletizing on growth performance, dietary energetics, and characteristics of digestive function for feedlot cattle. Anim. Feed Sci. Technol. 183:106-115.

SAS. 2007. User's Guide: Statistics Version 9, 6th edn. SAS Inst., Inc, Cary, NC, USA.

Van Soest, P. J., J. B Robertson, and B. A. Lewis. 1991. Methods for dietary fiber, neutral detergent fiber, and nonstarch polysaccharides in relation to animal nutrition. J. Dairy Sci. 74: 3583-3597.

Vasconcelos, J. T. and M. L. Galyean. 2007. Nutritional recommendations of feedlot consulting nutritionists: The 2007 Texas Tech University survey. J. Anim. Sci. 85:2772-2781.

Ware, R. A. and R. A. Zinn. 2005. Effect of pelletizing on the feeding value of rice straw in steam-flaked corn growingfinishing diets for feedlot cattle. Anim. Feed Sci. Technol. 123124:631-642.

Wolin, M. J. 1960. A theoretical rumen fermentation balance. J. Dairy Sci. 43:1452-1459.

Woodford, J. A., N. A. Jorgensen, and G. P. Barrington. 1986. Impact of dietary fiber and physical form on performance of lactating dairy cows. J. Dairy Sci. 69:1035-1047.

Zinn, R. A. 1986. Influence of forage level on response of feedlot 
steers to salinomycin supplementation. J. Anim. Sci. 63:20052012.

Zinn, R. A. and F. N. Owens. 1986. A rapid procedure for purine measurement and its use for estimating net ruminal protein synthesis. Can. J. Anim. Sci. 66:157-166.

Zinn, R. A. 1990. Influence of flake density on the comparative feeding value of steam-flaked corn for feedlot cattle. J. Anim. Sci. 68:767-775.

Zinn, R. A., A. Plascencia, and R. Barajas. 1994. Interaction of forage level and monensin in diets for feedlot cattle on growth performance and digestive function. J. Anim. Sci. 72:22092215.
Zinn, R. A., C. F. Adams, and M. S. Tamayo. 1995. Interaction of feed intake level on comparative ruminal and total tract digestion of dry-rolled and steam-flaked corn. J. Anim. Sci. 73:1239-1245.

Zinn, R. A., E. G. Alvarez, M. F. Montaño, A. Plascencia, and J. E. Ramirez. 1998. Influence of tempering on the feeding value of rolled corn in finishing diets for feedlot cattle. J. Anim. Sci. 76:2239-2246.

Zinn, R. A., F. N. Owens, and R. A. Ware. 2002. Flaking corn: Processing mechanics, quality standards, and impacts on energy availability and performance of feedlot cattle. J. Anim. Sci. 80:1145-1156. 